Received: 17 October 2019 Accepted: 22 October 2019

\title{
Tracing the Origins of the Morleys found in 18th Century Glamorgan
}

\author{
John O. Morley
}

\begin{abstract}
The origins of many families who moved to Glamorgan from the West Country and the Midlands during the early part of the Industrial Revolution are often unknown, as the parish registers are incomplete and official records did not appear until later in 1838. This study is concerned with tracing the origins of one such family, called Morley, who appeared in the Vale of Neath in the early eighteenth century. They were yeomen whose descendants became involved in the fledgling tinplate industry there as the family expanded. Links between early family members have been established by exploring their wills where available and original source material from the National Library for Wales. Further connections have been made possible by using the accepted English genealogical practice of tracing the family by following the sequence of family Christian names. This process has successfully enabled connections to be made between the family in Glamorgan and their antecedents in Carmarthenshire. The progenitor of this family has been identified as originating from Bayton in Worcestershire and it is believed that the family originally descended from the Morleys of Norfolk in the thirteenth century.
\end{abstract}

\section{Introduction}

During the Industrial Revolution in the UK, substantial numbers of workers migrated from the West Country and the Midlands to seek employment in the numerous coal mines, iron works and tinplate works that had sprung up throughout south Wales, especially in the counties of Glamorgan, Monmouth and Carmarthen. As a result many English surnames, such as Smith, Taylor and Brown, are ubiquitous, but other surnames such as Morley, which is the subject of this article, are less common, and arrived much earlier. For example, an earlier article has dealt with Sir John de Morley, the son of Baron William de Morley of Norfolk, who lived at Llansantffraed, near Raglan, in present day Monmouthshire, in the fourteenth century. ${ }^{1}$ Another account has described the trials and tribulations of the Sussex ironmaster, Anthony Morley, who arrived in Glamorgan near the end of the sixteenth century and died bankrupt. ${ }^{2}$ A further article has described the family of Walter Morley, a yeoman, who migrated from Worcestershire to Carmarthenshire during the same era. ${ }^{3}$ Yet by the time of the 1841 National Census, there were only 67 people listed in the whole of Wales with this surname, of whom 53 were present in Glamorgan and eight in Carmarthen. Sixty years later, at the time of the 1901 Census, the overall number in Wales had risen, but only to $236 .^{4}$

This present account describes an investigation of the antecedents of the Morleys, found in Glamorgan during the 18th century, using the well-established English genealogical practice of tracing the family by following the sequence of family Christian names. Traditionally, the first son of a marriage was named after the father's father, the second was named after the mother's father, the third after the husband, and the third and fourth sons were named after the father's older brother(s) or sometimes after the father's uncle or mother's oldest brother(s). ${ }^{5} \mathrm{~A}$ number of very important caveats should be added: if the father's father and his father-in-law shared the same name, the second son, not the third would be named after the husband; if the husband and his father shared the same name then the third son of the marriage would be named after the eldest brother. Similarly, the first daughter of a marriage was named after the mother's mother, the second named after the father's mother and the third after the mother and so on with the same caveats as before. In the unlikely event that the husband, his father and his father-in-law all shared the same name then the second son would be named after his brother. This approach is fraught with difficulty

(0) 2020 The Author(s). This is an open access article distributed under the terms of the Creative Commons Attribution License (http://creativecommons.org/ licenses/by/4.0/) 
however, as the sequence is often disrupted when a child has been named after a grandparent, but it dies before it has been christened, so that the name does not appear in the parish registers. Under these circumstances, the first child recorded is not called after the father's father or the mother's mother but is the next in sequence. This situation can often be detected when there is a significant lapse of about three years either between the date of marriage and the birth of the first surviving child or between the dates of birth of two consecutive surviving children. Following the premature death of a child in this manner, the name was very often re-used for a later child. In contrast, the Welsh Patronymic naming system, ${ }^{6}$ which was used by several Welsh families in the Vale of Neath at this time, does not follow the same guidelines described above.

\section{Known Morleys in 18th Century Glamorgan}

A previous article has discussed the life of William Morley of the parish of Cadoxton-juxta-Neath (henceforth Cadoxton) in the Vale of Neath in Glamorgan. ${ }^{7}$ Very unusually he lived until the age of 98 in the second half of the eighteenth century and raised a large family (Table 1) who all predeceased him. He owned land in the hamlet of Neath Genol (middle Neath), which lay about 10 miles northeast of the town of Neath, on the western side of the River Neath in the vicinity of Aberpergwm, and near the parish of Ystradyfodwg on the eastern side of the river, where several other Carmarthenshire families were known to have migrated in the early nineteenth century. These incomers were known as 'Glorans' and they were mainly yeomen or small tenant farmers. Their farms were often small and although they were respectable people, their economic state was often poor. ${ }^{8}$ William Morley (L1) ${ }^{9}$ married Elinor John on Saturday 29 April 1752 at the parish church of St. Catwg in Cadoxton (Figure 1). The marriage entry in the register by William Thomas, the Vicar, states that both William (L1) and Elinor were from the parish of Cadoxton but there is no record of their baptisms because the early parish registers have been lost and the first entries only start in 1738. Although the bishop's transcripts for the parish date from 1721, the entries in many places are unfortunately illegible. Their first child, William (M1), was born on 28 Jan 1753 and overall they had eight recorded children during the next 18 years (Table 1).

Table 1. Baptisms taken from the Parish Registers or other sources in the Vale of Neath with the Father's surname given as Morley.

\begin{tabular}{|c|c|c|c|c|c|}
\hline Father & Mother & Child & DoB $^{a}$ & $\mathbf{P}^{\mathbf{b}}$ & Comments $^{\mathrm{c}}$ \\
\hline \multirow[t]{3}{*}{ William (K1) } & Anne (see text) & William (L1) & 1716 & $\mathrm{CN}$ & d. Neath, 1814, aged 98 \\
\hline & & Thomas (L1) & $\sim 1722$ & LN & Alive 1758 \\
\hline & & Walter (L1) & 31 Jul 1726 & $\mathrm{CN}$ & Bishop's transcripts. \\
\hline Walter (L2) & Unknown & Thomas (M2) & 21 Aug 1741 & $\mathrm{CN}$ & Thomas, Son of Walter Morley - Llanboidy \\
\hline \multirow[t]{8}{*}{ William (L1) } & Elinor John & William (M1) & 28 Jan 1753 & $\mathrm{CN}$ & Son of $W^{m}$ Morley \\
\hline & & Thomas (M1) & 28 Jun 1755 & $\mathrm{CN}$ & Son of $W^{m}$ Morley \\
\hline & & Walter (M1) & 31 Dec 1757 & $\mathrm{CN}$ & Son of $W^{m}$ Morley \\
\hline & & Anne & 07 Mar 1761 & $\mathrm{CN}$ & D. of $W^{m}$ Morley, NG \\
\hline & & Evan (M1) & 26 Jan 1763 & $\mathrm{CN}$ & Son of $W^{m}$ Morley \\
\hline & & Elinor & 11 Aug 1765 & $\mathrm{CN}$ & Dau of $W^{m}$ Morley \\
\hline & & George & 06 Mar 1768 & $\mathrm{CN}$ & Son of $W^{m}$ Morley, d. 1770 \\
\hline & & Mary & 14 Dec 1771 & $\mathrm{CN}$ & D. of William Morley \\
\hline \multirow[t]{2}{*}{ Thomas (L1) } & Mary & William (M2) & 11 Feb 1758 & LN & S. of Thomas and Mary \\
\hline & & Evan (M2) & 21 June 1760 & LN & S. of Thomas and Mary \\
\hline \multirow[t]{5}{*}{ Thomas (M1) } & Catherine Hopkin & Sarah & 10 Dec 1774 & $\mathrm{CN}$ & Dau of Thomas Morley \\
\hline & & Mary & 14 Nov 1776 & $\mathrm{CN}$ & Dau of Thomas Morley \\
\hline & & Margaret & 29 Mar 1780 & $\mathrm{CN}$ & D. of Thomas Morley \\
\hline & & Thomas (N1) & 27 Feb 1782 & $\mathrm{CN}$ & S. of Thomas Morley \\
\hline & & William (N1) & 23 Jun 1784 & $\mathrm{CN}$ & S. of Thomas \& Catherine \\
\hline \multirow[t]{5}{*}{ William (M2) } & Mary Owen & Thomas (N2) & 06 Apr 1783 & LN & Thomas Son of $W^{m}$ Morley \\
\hline & & Evan & 1784-93 & LN & Died 1794 \\
\hline & & David & 1779-83 & LN & Author's assignment \\
\hline & & William (N2) & 1786 & $\mathrm{LN}$ & Author's assignment \\
\hline & & Charles & $1788-92$ & LN & Author's assignment \\
\hline \multirow[t]{3}{*}{$\operatorname{Evan}(M 2)^{\mathrm{e}}$} & Jennet Jenkin ${ }^{f}$ & Thomas (N3) & 24 Dec 1791 & LN & Son of Evan Morley \\
\hline & & Mary & 26 Jan 1794 & LN & D. of Evan Morley \\
\hline & & Ann & 1801 & LN & Died 1812 \\
\hline
\end{tabular}

a Date of baptism. The precise dates shown are taken from the parish registers; the remainder have been taken from the 1841 and 1851 census returns for Glamorgan. ${ }^{b}$ Parish: $C N=$ Cadoxton Juxta Neath; $L N=$ Llantwit Juxta Neath. ' Comments in italics are quoted verbatim from the register. The author's assignments are based on circumstantial evidence discussed in the previous article on this theme. 

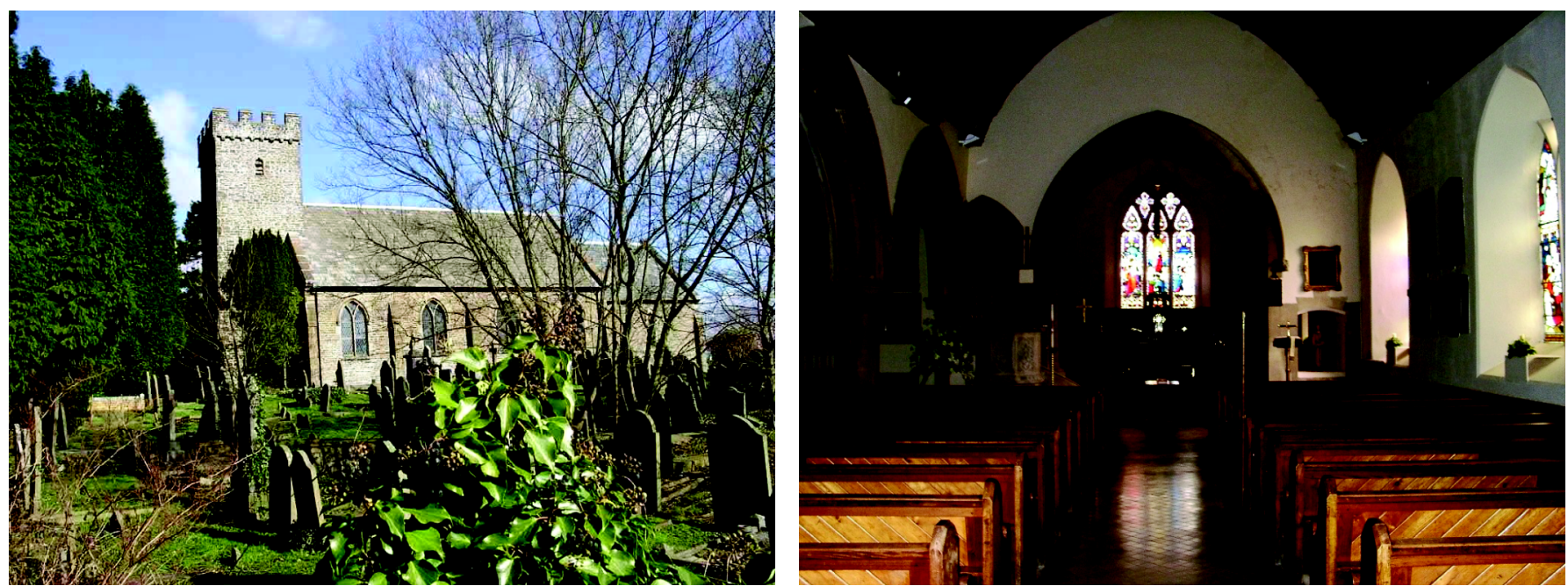

Figure 1. St. Catwg's Church in Cadoxton (Photographed by the author 18 November 2004).

Prior to the date of their marriage, there are only two other recorded occurrences of the surname in the parish registers of Cadoxton, one on 31 July 1726, with the birth of a Walter Morley, and the second on 21 August 1741, with the birth of a Thomas Morley (M2). The name also occurs in the neighbouring parish of Ystradyfodwg with the death of a Mary Morley and her illegitimate daughter in 1740, placing her birth to $1720 .{ }^{10}$ William Morley (L1) died on the 30 December 1814, aged 98, according to the unequivocal entry in the parish register by William Williams, the Vicar of St. Catwg's at that time. This places his birth to 1716, which implies that William (L1) was 36 years old when he married Elinor John. This was not unusual as the mean age of marriage from 1600 to 1750 in England and Wales was 28 for men and 26 for women, ${ }^{11,12}$ though these figures can be misleading as they conceal a wide variation of age at first marriage. A similar pattern emerges for the marriage age of women which suggests that Elinor John may have been born in 1726 and not in 1731 as previously reported. ${ }^{13}$ Although this pattern applied to most working people who were obliged to save up to acquire enough belongings to set up a home, it did not apply to the more wealthy middle classes men or to women who were often able to marry at the age of majority especially in the late sixteenth century. ${ }^{14}$

As previously indicated, the Morley name was not common in the Vale of Neath prior to 1716 as it does not appear in the early registers of marriages, baptisms, or burials in Cadoxton JN, Neath, Cilybebyll, Llantwit-juxta-Neath (henceforth Llantwit) or the town of Neath from 1638 to $1679 .{ }^{15}$ There is no mention of the name either in the churchwardens accounts for the parish and town of Neath from 1674 to $1700,{ }^{16}$ nor are there any Morleys recorded in the Hearth Tax roll of 21 February 1670-71 in any parish in the Vale of Neath, ${ }^{17}$ nor indeed does the name occur anywhere else in Glamorgan at the time of this tax. ${ }^{18}$ Furthermore, an examination of the existing parish records or bishop's transcripts for Cadoxton, ${ }^{19}$ Llantwit $^{20}$ and the town of Neath ${ }^{21}$ dating from 1692 in some cases, and in others from 1738 , up to 1750 shows no further occurrence of the name excepting the entries mentioned above. All of this information strongly suggests that the family had moved to the Vale of Neath in the early eighteenth century probably from nearby Carmarthenshire as suggested in a previous article.

That William Morley (L1) called his first son, who was born nine months after his marriage on 28 Jan 1753, William (M1), strongly implies that his father had the same name also (Table 1). If the usual convention had been followed, his second son, called Thomas (M1), would have been named after his wife's father, who was possibly one of three Thomas Johns, who were alive at this time as deduced from the dates of their burials, in Cadoxton, in the expected period of 1750-90. One of these died at Aberpergwm in 1772, ${ }^{22}$ near the hamlet of Neath Genol where William Morley (L1) is thought to have resided. Details of the births and marriages of these people do not exist because the parish registers have been lost as stated earlier, but if this Thomas John was the father of William's wife, Elinor, he would have married around 1725 and been born around 1700. The alternative possibility that Elinor's father was called William, however, rather than Thomas, cannot be completely discounted, and in this scenario, Thomas (M1) would have been named after William (L1)'s elder brother while his third son, Walter (M1), would have been named after another brother assuming the usual naming conventions applied (see later).

Elinor had three daughters, Anne, Elinor and Mary, and if the usual naming pattern had been adopted, the first of these would have been named after her mother and the second after her mother-in-law. This indicates that her mother was called Anne, and her mother-in-law Elinor, 
but because there is a noticeable gap of over three years between the birth of her third child, Walter, on 31 December 1757 , and the birth of her first daughter, Anne Morley, on 7 March 1761, this suggests that another child, perhaps a daughter, may have been born in 1759, but did not survive. If so, this may indicate that Anne was named after William (L1)'s mother and the second daughter named after Elinor herself or perhaps her mother, as an Elinor John was alive in the neighbourhood at this time, as indicated by her later burial in Cadoxton in 1773 (though no husband is named in the register). ${ }^{23}$

As William (L1) was born in 1716, his father, the putative William Morley (K1), would have married a year or so earlier and been born in the late seventeenth century. The will of Thomas Bevan of Cadoxton, dated $1731,{ }^{24}$ is thought to identify this William (K1), and one of his sons, called Thomas (L1). In his will, Thomas Bevan bequeaths a lamb to each his three grandsons: Thomas Morley, the son of William Morley; Thomas Bevan, the son of Evan Thomas; and Richard Thomas, the son of Thomas Richard. His wife, Elinor David [Bevan], and son, David Thomas [Bevan], received the remainder of his estate. It follows that William Morley (K1) had married a daughter of Thomas Bevan, probably the eldest one, as their son Thomas Morley, is mentioned first. Significantly, this son is named after his wife's father, which is presumably why he was favoured, but he would have been the second son of this marriage assuming that the usual naming convention had been followed. Given that William (L1) was probably the first son of this marriage, Thomas Morley (L1) was born in 1718 at the earliest, and perhaps 1720 or 1722 if there were any intervening daughter(s). As Thomas Bevan died in 1730 (probate was granted on 21 January 1731), he would have been born around 1660 at the earliest assuming a biblical life span, and married about 1688. His first child, possibly his eldest daughter, would have been born around 1689 , placing her marriage to William Morley (K1), about 1715, assuming she had by then attained the average age of 26 discussed earlier.

The Morleys were present also in the adjacent parish of Llantwit. The parish registers report the birth of a William Morley (M2) on 11 February $1758{ }^{25}$ and an Evan Morley (M2) on 21 June 1760, ${ }^{26}$ with their parents named as Thomas Morley (L1) and Mary Morley in both cases (Table 1). Thomas (L1) would have married Mary in 1757 at the very latest, and possibly several years earlier if there had been any older daughters, though surprisingly there is no record in the parish registers of this marriage or their births. That there are no further children recorded suggests that Thomas (L1) may have died a few years after Evan's birth, perhaps as a result of a coal mining accident, as there is no record of him at all or his burial. That Thomas (L1) called his first son, William (M2), strongly implies that his father was called William also, and it is suggested that this person was William (K1), making William (L1) his elder brother. They clearly lived in the same locality as the parish of Llantwit lies adjacent to Neath Genol (Figure 2). ${ }^{27}$

The Bishop's Transcripts for Llantwit, record the death of "Mary Wife of Thomas Morley" on 20 May 1775, who is thought to be the widow of Thomas Morley (L1); no age is given though she was probably only about 50 years old when she died assuming that she was roughly the same age as her husband, Thomas (see later). It is likely that her second son, Evan, was named after her father. The implied date of her marriage, perhaps as early as 1754, places Thomas (L1)'s birth to around 1726, but given that his elder brother William was 36 when he married, it is possible that Thomas also was also around the same age when he married, placing his birth to about 1720 . It seems likely that the Walter Morley (L2), who was baptised on 31 July 1726 in Cadoxton, was also the son of William (K1). This notion is strongly supported by the names of

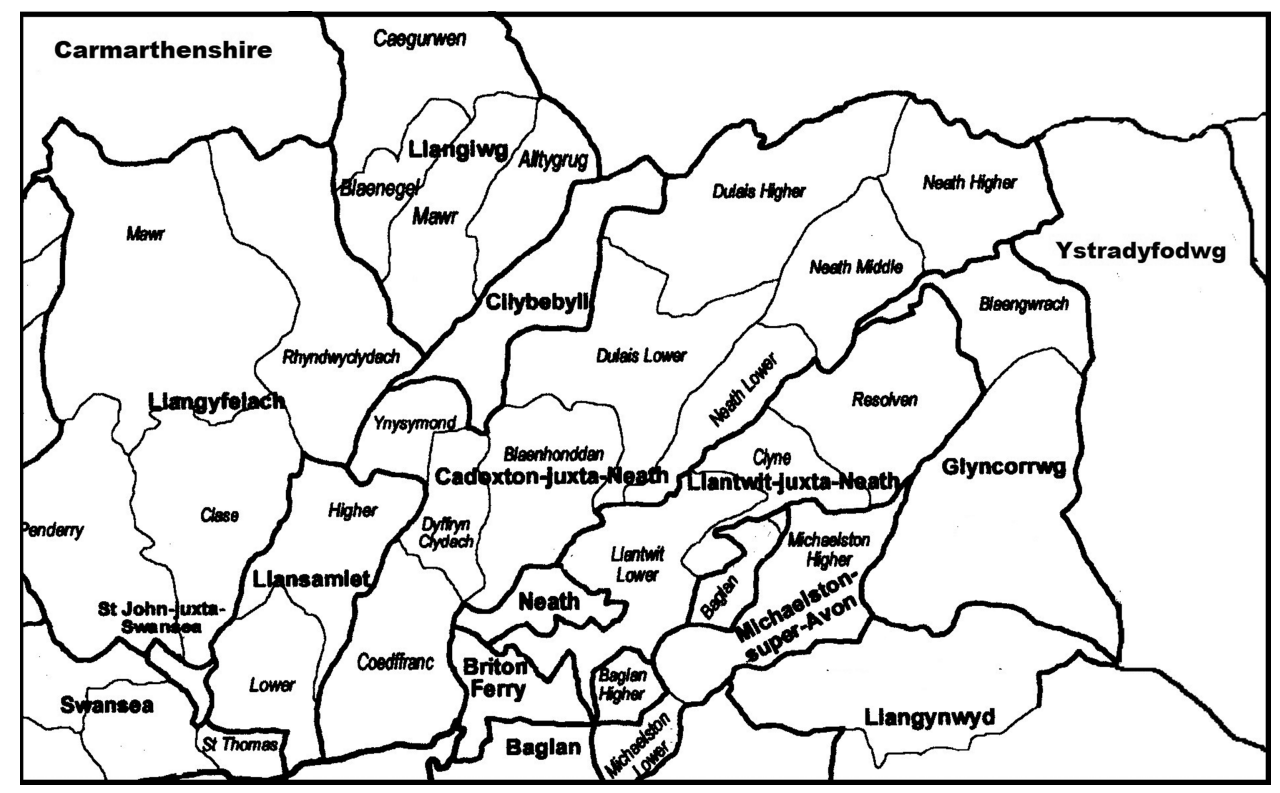

Figure 2. Ancient Parishes of West Glamorgan 
William (L1)'s sons (Table 1). His first son was named after his father, William (K1), the second after Elinor's father, Thomas, as indicated earlier, and the third would normally have been named after himself or his brother, Thomas (L1), but because both these names had already been used, he called this son after his second brother, Walter (L1). This implies that William (K1) may have had at least three sons, William (L1), Thomas (L1) and Walter (L1), and probably several daughters but their names have been lost through marriage.

There is no extant record in the Bishop's Transcripts or parish registers for the Vale of Neath of William (K1)'s father, the putative William (I). A contemporary of William Morley (L1) was alive around this time, possibly his cousin, who was called Walter Morley (L2); he was the father of a Thomas Morley (M2), born in Cadoxton on 21 August 1741. The entry in the parish register (Table 1) states that he was from, or had gone to, Llanboidy in Carmarthenshire. However, there are no Morleys recorded in the parish registers in Llanboidy suggesting that he went there for work. Walter (L2) would have married by 1740 and possibly earlier if he had other children. This places Walter (L2)'s marriage to 1740 at the latest and his birth to about 1712. There is no further record of Walter (L2), his son Thomas (M2), or any other members of his family in the Vale of Neath thereafter, suggesting that he had left for Carmarthenshire (see later). However, the parish registers for Carmarthenshire report the marriage of a Mary Price to a Thomas Morley on 26 August 1766 in Llandeilo Fawr, and it seems plausible that this person was Thomas (M2) who was around 25 years old at that time. His wife Mary Morley is believed to be the person who died on 13 November 1801 in Llandeilo Fawr. $^{28}$

In a previous account of the Morleys it was indicated that the Thomas Morley who married Catherine Hopkin in Cadoxton on 11 November 1773 was William's son Thomas (M1). ${ }^{29}$ However, this new study which is based on the naming conventions used for their children, casts some doubt on this assignment. Thomas and Catherine named their first daughter, Sarah, after her mother, who was perhaps the Sarah David who married William Hopkin in Llantwit-juxta-Neath on 28 April $1742 .^{30}$ This assignment is supported by the presence of W. Hopkins and Jennet David as witnesses to Catherine's marriage in 1773. The witnesses were probably Catherine's father and her mother's sister or other relation.

That Thomas (M1) and Catherine named their second daughter Mary, not Elinor, and their first surviving son Thomas (N1), not William, suggests that Catherine's husband was not the son of William Morley (L1) but perhaps an unrecorded son of Thomas Morley (L1) and his wife Mary (Table 1). However, Thomas (L1)'s son, William (M2), who was born in 1758, was almost certainly named after his father, William (K1), and therefore he was his first son. It follows that if another son existed, he would have been born after Thomas (LI)'s second son, Evan, in 1762, making him only 11 years old at the time of Catherine Hopkin's marriage in 1773. In a different interpretation, the gap of over three years between the birth of Thomas (M1)'s second daughter Mary in 14 November 1776 and her sister Margaret in 29 March 1780 (Table 1) implies that there was another child, possibly called William who died before he was christened. If so, he would have been named after both Thomas's father and his father-in-law.

Their next surviving son, Thomas (N1), would have been named therefore, after Thomas (M1) himself in line with the usual convention. That they called their second surviving son, William (N1), supports this hypothesis as often the same name was used again after the death of the first son as indicated earlier. If this scenario is correct, it is difficult to understand why Thomas and Catherine called their second daughter Mary and not Elinor. One explanation may be that there was some form of family dispute as Thomas was only 18 years old when he married the 29year old Catherine. This would explain why the two witnesses to their marriage came from Catherine's side of the family only, whereas usually one of these would have been drawn from Thomas's side. Mary, their second daughter may have been named after the Mary Hopkin(s) who was born in Cadoxton in 1751 and who died a year later. ${ }^{31}$ Because her father was named as William [Hopkin] in both register entries it is possible that she was Catherine's younger sister.

The third alternative possibility that the Thomas (M2) who married Catherine was the son of Walter (L2) rather than William (L1) cannot be discounted (Table 1) as he would have been 32 years old and a similar age to Catherine in 1773. However, there are sound reasons for the assignment of Thomas (M1) as her husband, made in the original study, ${ }^{32}$ which are reinforced by the observation that none of Thomas (M1)'s sons were called after Walter (Table 1). In the previous study, it was assumed that both the William Morley (M2) who married Mary Owen on 28 July 1781, and the Evan Morley (M2) who married Jennet Jenkin on 26 February 1791, in Llantwit, were the sons of William (L1). However, this investigation, based in part on the naming conventions applied to their children, rules this out as William (M2) called his first son, who was born about 18 months after his marriage, Thomas (N2), and not William (Table 1). Likewise, Evan (M2) also called his first son, who was born about 10 months after his marriage, Thomas (N3). Both their sons therefore were named after their father Thomas (L1)

\section{The Carmarthenshire Connection}

William Morley (K1), the father of William (L1) and Thomas (L1), was possibly 30-35 when he married given that both of his sons were married in their mid-30s; if so, he was born as early as 1680 . The absence of any Morleys at all in Glamorgan at this time strongly indicates that William 
(K1) was a member of the well-established Morley family who lived in neighbouring Carmarthenshire. The progenitor of this family was a Walter Morley (G), born in 1566 in Bayton, Worcestershire, who had moved to Llangathen in the late 1590s; he had four children (see later). Two previous articles have discussed the genealogy of the Carmarthenshire Morleys ${ }^{33}$ based in part on information from the Golden Grove Book of Pedigrees, ${ }^{34}$ the so-called Bainbridge/Brigstock Typescript or Manuscript, which lists early events in the county from 1680 to the early $1700 \mathrm{~s}^{35}$ and the wills of Walter Morley (G) of Llangathen ${ }^{36}$ and John Lewis Morgan of Llangadock. ${ }^{37}$

In Walter (G)'s will, dated 12 May 1640, his wife, Joyce, is named as the main beneficiary of his estate with the caveat that it was to be equally divided between his two sons, Thomas $(\mathrm{H})$ and Walter $(\mathrm{H})$, on her death. His married daughters Frances Gibens and Joyce Sidnam and granddaughters Jane and Sage were also beneficiaries. Unusually, Walter and Joyce had no further children after the birth of their fourth child. Walter (G)'s grandson, also named as Walter Morley, was bequeathed a yearling (a one year old horse). The will was witnessed by William Hughes (clerk), Thomas Morley $(\mathrm{H})$ his elder son, Robert Sidnam, his son in law, and William Taylor. Probate was granted on 3 July 1643 indicating that Walter (G) had died about April 1643, aged around 77, and almost certainly interred in St Cathen's Church (Figure 3). However, the named executors of Walter's will were Joyce, his wife, and Walter Morley $(\mathrm{H})$, his younger son, but significantly not his elder son, Thomas (H), who had witnessed the will in 1640 .

This strongly suggests that he had died during the intervening three years. Thomas $(\mathrm{H})$ was born in 1595 and was clearly married by 1637 as shown by an indenture dated 13 July $1637^{38}$ involving the transfer of property from Katherine Rutherch, a widow of Llanedie in Carmarthenshire, to Thomas Morley also of Llanedie, and Jane his wife. The indenture is qualified with the statement "to the heires and assignes of the said Jane forever" implying that Jane was related to Katherine Rutherch and possibly her niece or even her daughter although this is not stated directly. It seems possible therefore that her maiden name was Jane Rutherch. No grandchildren are named implying that Thomas and Jane had no children.

It is now thought that Walter (G)'s son, Walter (H), married John Lewis Morgan's daughter, Joyce, about 1628, and Morgan's will, dated 28 January 1649 , discloses that they had eight surviving children at that time who were born in Llangathen. These were: Rice (or Rees) and Henry, who are named first and clearly his favoured grandsons, and then in sequence: Frances, Katherin, John, Walter, Thomas, and William (Table 2). Another daughter, Rachel, was born after Morgan's death according to the Golden Grove Book of Pedigrees, who married Jenkin Lloyd. The marriage date, which is later than that proposed in an earlier study by the author, is based on a fertility period of about 20 years for women in this era and maximum age for conception of about 45 years. ${ }^{39}$ As Rachel was born late in 1649, this suggests that Joyce's first child would have been born around 1529 at the very earliest, and her last child born when she 45 years old, placing her birth to about 1604 at the earliest. On this measure, she died in 1691 aged about 87 though her husband Walter $(\mathrm{H})$ had predeceased her in 1689, aged around 90-92. This unusual longevity appears to have inherited by his grandson William (L1) who lived until the age of 98 as indicated earlier. Walter (H)'s estate would not have been large enough to accommodate all his sons once they had reached maturity and they would have been forced to move to elsewhere.

It is thought that Walter (H)'s first son was named after his father Walter (G), and born about 1629. This son, Walter (I1), is referred to in the latter's will of 1640, where he is left a yearling implying that he was old enough to ride a horse at that time. However, confusingly there
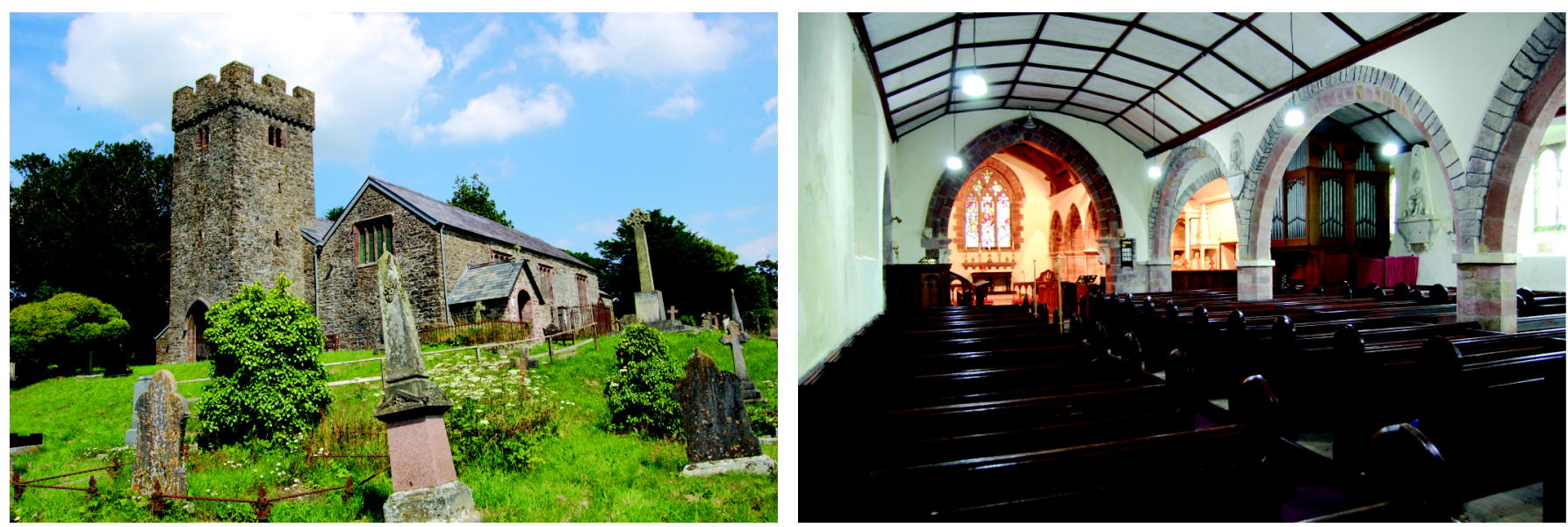

Figure 3. St Cathen's Church in Llangathen (Photographed by the author on 8 August 2012). 
Table 2. Descendants of Walter Morley $(\mathrm{H})$ and Joyce Morgan of Llangathen. ${ }^{\mathrm{a}}$

\begin{tabular}{|c|c|c|c|c|c|c|}
\hline Child and spouse & DoB1 & DoMEst. & DoD & Grandchildren & DoB2 & Notes/Comments \\
\hline Walter (I1) & 1629 & & $1641-2$ & & & Surmised, see text \\
\hline Frances & 1631 & 1657 & & & & \\
\hline Katherin & 1633 & & 1684 LF & & & \\
\hline Henry (I) m. Eliz. David & 1635 & 1663 & 1713 LG & Walter & 1687 LG & $\begin{array}{l}\text { Elizabeth uxor Henrici Morley d. 1685. Walterus } \\
\text { filius Henrici Morley; m. 1709; d. } 1761 \text { LG }\end{array}$ \\
\hline Rees (I) m. Catherine Williams & 1637 & 1675 & 1710 LF & $\begin{array}{l}\text { 1. Walter } \\
\text { 2. Edward } \\
\text { 3. Margaret }\end{array}$ & $\begin{array}{l}1679 \mathrm{LF} \\
1681 \mathrm{LF} \\
1683 \mathrm{LF}\end{array}$ & $\begin{array}{l}\text { Surmised, see text } \\
\text { Edward son of Rees. He d. } 1703 \\
\text { m. Thomas Phillips } 1709\end{array}$ \\
\hline John & 1639 & 1667 & 1699 LG & $\begin{array}{l}\text { 1.Walter } \\
\text { 2. John }\end{array}$ & 1668 LG & $\begin{array}{l}\text { Surmised, see text } \\
\text { m. Jane Hugh, } 1696\end{array}$ \\
\hline Walter (I2) & 1643 & 1671 & 1693 LF & $\begin{array}{l}\text { 1. Walter (J1) } \\
\text { 2. William (J1) }\end{array}$ & $\begin{array}{l}1672 \mathrm{LF} \\
1674 \mathrm{LF}\end{array}$ & $\begin{array}{l}\text { m. Eliz.Williams, } 1697 \text { d. } 1745 \text { LB } \\
\text { m. Catherine ?, 1700; d. } 1712 \text { HMS Bristol }\end{array}$ \\
\hline Thomas (I)m. Mary & 1645 & 1673 & 1718 LF & $\begin{array}{l}\text { 1. Walter (K2) } \\
\text { 2. Rees (K) }\end{array}$ & $\begin{array}{l}1681 \mathrm{LF} \\
1682 \mathrm{LF}\end{array}$ & $\begin{array}{l}\text { Walter son of Thomas, d. } 1750 \text { LF } \\
\text { First son Thomas b. } 1702 \text { LB }\end{array}$ \\
\hline William (I) & 1647 & 1675 & 1717 LB & $\begin{array}{l}\text { 1.Walter (K1) } \\
\text { 2. William (K1) }\end{array}$ & $\begin{array}{l}1679 \mathrm{LB} \\
1685 \mathrm{LB}\end{array}$ & $\begin{array}{l}\text { Surmised, see text } \\
\text { Alive } 1731 \mathrm{CN}\end{array}$ \\
\hline Rachel m. Jenkin Lloyd & 1649 & 1676 & 1701 LB & & & \\
\hline
\end{tabular}

${ }^{a}$ The dates of birth of Walter $(\mathrm{H})$ 's children (DoB1) have been estimated in part from the Will of John Lewis Morgan of Llangadog as previously reported by the author. Their date of marriage (DoM) is either based on the DoB of the first child of a marriage or it has been assumed that men marry at 28 and women at 26 (see text). The places and dates of death (DoD) are taken from parish records. The dates of birth of Walter (H)'s grandchildren (DoB2) have been taken from parish records or estimated. Entries in italics are taken from the Bishop's Transcripts or in the Bainbridge/Brigstock Manuscript. The dates shown in red are reliable and taken either from parish records or from contemporary documents as reported previously (see text). Key: $L F=L$ landeilo Fawr; $L B=L$ landybie; $L G=L$ Llangadog; CN = Cadoxton Juxta Neath.

appears to have been another son also named Walter (12), who was born later in 1644, strongly suggesting that the first son had died after Walter (G) had made his will, but before probate had been granted in 1643. This information implies that Walter (I1) had died between May 1640 and April 1643, around the same time as his uncle, Thomas Morley (H). Incontrovertible evidence for the birth of this second son is provided by records of a dispute over the payment of goods between Walter $(\mathrm{H})$, who was the petitioner in the action, and Margaret Search, Thomas Search, her son, and Jacob Strange, who were the defendants. This dispute was examined on 17th January 1665 in Llandeilo before John Davis, Rowland Prichard and Thomas Lowe, who were acting on behalf of His Majesty's High Court of Chancery. This document unequivocally places the dates of birth of Rees (I) to 1637-38, Walter (I2) to 1643-4, and John, described as a merchant (mercer) in Llandeilo, to 1639 or before. ${ }^{40}$ Walter $(\mathrm{H})^{\prime}$ s eldest surviving son, Henry, is not mentioned in this action implying that he had possibly married and moved away by this date. Furthermore, neither Thomas (I) nor William (I) are involved either, because they were both less than 21 years old at the time. It is thought that Walter (I2) was born shortly after Walter (I1) had died and it appears that it was sometimes the custom to give a newborn child the same first name as an elder sibling, especially if the elder child had died, and the name adopted was the same as that of the head of the family. ${ }^{41}$

Walter (G) had originally leased land from Sir John Vaughan of Golden Grove, the first Earl of Carbery, who was an important landowner in Carmarthenshire. This is disclosed in the Cawdor Vaughan Muniments which show a transaction ${ }^{42}$ dated 1 August 1613 'between Sir John Vaughan of Goulden Grove and Walter Morley of Llangathen, yeoman, Joyce his now wife, and Thomas Morley their son.' Vaughan's brother, Sir Henry Vaughan, was also a prominent landowner and the MP for Carmarthenshire, and Walter (H)'s second son, Henry, was possibly named after him. One possible explanation for the deaths of Thomas $(\mathrm{H})$ and Walter (I1) between 1640 and 1643 may be attributable to the Civil War which started in earnest in the autumn of 1642, when many Welshman who were enlisted in the Royalist army, were slaughtered in several early internecine encounters with the Parliamentarians. It is possible that both Thomas $(\mathrm{H})$ and Walter (I1) may have been involved in some way though the possibility that they died from other causes cannot be discounted.

In the list of Walter $(\mathrm{H})$ 's children it has been assumed that both daughters preceded Henry but this may not be so. However, the first daughter Francis was possibly named after Walter $(\mathrm{H})$ 's elder sister and the next, Katherin, possibly named after a relative of Luce. It is thought that some of Walter (H)'s sons married rather late in life as Rees (I)'s first recorded son, Edward, was not born until 1681 and his daughter Margaret, who married Thomas Phillipps in 1709, was probably born around 1683. Edward died in 1703. Assuming that Rees (I) would have named his first son, Walter (after his father), this child would have been born about 1679, placing Rees (I)'s marriage to roughly 1678 making him almost 40 years old at the time. However, an Administrative Bond, ${ }^{43}$ dated 1710, the year he died, only refers to his daughter Margaret and her husband Thomas Phillipps, who lived at Pentre, Llandeilo Fawr. ${ }^{44}$ This strongly implies that there were no other surviving children. Henry Morley, Walter $(\mathrm{H})$ 's the eldest son, may have married twice, as first wife, Elizabeth David, died 10 September 1685 and his only recorded son, Walter, was baptized 23 May 1687. This suggests that either he had married again by mid 1686 or that Elizabeth had died in childbirth and Walter's baptism had been deferred out of respect to his mother. 


\section{The Identity of William Morley (K1)}

It is clear that William (K1) was born in the era that Walter Morley (H)'s sons would have married and it seems reasonable to suppose that his father was one of the six sons listed in Table $2 .{ }^{45}$ Significantly, the absence of any male descendants of either William (L1)'s family in Cadoxton or Thomas (L1)'s family in Llantwit (see Table 1), who were called after any one of Walter (H)'s three eldest sons, Henry, Rees (Rice), or John, strongly suggests that none of these were William (K1)'s father. Their dates of birth also tend to rule them out of contention. Both Henry and Rees appear on the Hearth Tax returns for Carmarthenshire in $1670^{46}$, with the former taxed on four hearths in the Parish of Llangadog, and the latter taxed on two hearths in the nearby Parish of Llandeilo Fawr. The same Hearth Tax records show that their father, Walter $(\mathrm{H})$, was taxed on three hearths in the hamlet of Manor Fabon also in the Parish of Llandeilo. At least two of his sons, therefore, were well off, especially Henry, as only a small percentage of the dwellings in the Hearth Tax entries, registered more than one hearth. Of the remaining sons, neither Walter (I2), Thomas (I) nor William (I), appear in this tax return suggesting that they were not well off, and were perhaps tenant farmers. However, any one of these could be a possible antecedent of William (K1), as all of these names regularly appear in the list of his descendents in the Vale of Neath (Table 1).

In chronological order, it is thought that Walter (I2) can be ruled out as his father, because he was very probably the father of Walter Morley (J1), and another William Morley (J1). It is known that Walter (J1) married Elizabeth Williams in Llandybie in June $1697,{ }^{47}$ placing his birth to about 1676 at the very latest (at the age of majority), and earlier in 1672, if his father, Walter (I2), had married at the average age of 28 in 1671. It is thought that Walter (J1) and William (J1), or possibly William (I), were two of the signatories to an administrative bond, dated December 1697, which concerned the estate of Elizabeth Griffith of Llandeilo Fawr (the grandmother of Walter's wife Elizabeth). ${ }^{48}$

William Morley (J1), thought to be the younger brother of Walter (J1), had married around 1700 and moved to Llangyfelach, but in 1708 he joined, or was pressed into service in, the Royal Navy as previously disclosed. ${ }^{49}$ He died in service in 1712 according to an administrative bond ${ }^{50}$ leaving two surviving children, named William (K2) and Elizabeth, described in the legal document as infants, ${ }^{51}$ who were brought up by his brother Walter (J1) in Llandybie probably from the date he joined the Navy. It is thought that William (J1) had married his wife in Llangyfelach and they lived there prior to her death. He did not however own land there as the bond refers only to his "goodes chattells \& credittes". Nonetheless, it appears that he lived close to William (K1) as the parish of Llangyfelach is adjacent to Cadoxton (Figure 2).

Walter (J1) and his wife Elizabeth had many children but the gap between the date of their marriage and the birth of their first daughter, Anna Morley, in 1700, suggests that they may have had an earlier child, who was born in 1698, but who died before 1703, because only Walter (J1)'s first two daughters, Anna and Mary, are named in the will of Edith Griffith, dated $1703 .{ }^{52}$ Anna was perhaps named after Elizabeth's mother, Anna Williams, who may have been the person buried on 18 Feb 1730 in Llandybie. ${ }^{53}$ Walter (J1)'s second daughter, Mary, was born in 1702 , and possibly named after his mother, with his third daughter, born in 1704, named Elizabeth, presumably after his wife, implying that the family had adopted the usual naming convention. Because his next child, born 1706, was called Gabriel not Walter, it is thought that he would have been named after Elizabeth's father, supporting the notion that they had an earlier son, born perhaps in 1698, who died and was called after his father Walter (12). Gabriel was not a common name at this time in Carmarthenshire, but it is conceivable that her father may have been the Gabriel Lewis who married in 1670 in Tre-Lech A'r Betws. ${ }^{54}$ Walter (J1) did not call his next son, born in 1708, after himself, as expected, but John, who was possibly named after Walter (J1)'s father's elder brother. This almost certainly implies that he had a first son who died, who was called Walter. None of Walter (J1)'s subsequent sons were called Walter either, nor were they called after his brother, William (J1), because the latter's son, William (K2), had joined and formed part of his family in Llandybie from at least 1708 onwards.

The parish records show that William Morley (K2) married Mary John in Llandybie in $1721 .^{55}$ It seems unlikely that he had by then reached the age of majority, suggesting perhaps that this was a shotgun marriage, but if so, this child did not live, and indeed the first child of this marriage, Anna, was not born until $1726,{ }^{56}$ and possibly named after Mary's mother. This suggests that there may have been up to two children who were born and died before Anna, and possibly named after his father, William (J1), and/or uncle, Walter (J1). That none of his subsequent sons were called by either of these names is supportive. Indeed his first son, born in 1728, was called Gabriel presumably after his close cousin who he was raised with in Walter (J1)'s house. William (K2)'s second daughter, born in 1728, was named Catherine and possibly called after his mother. It is not known with any certainty what became of William (K2)'s sister, Elizabeth, but the burial of an Elizabeth Morley in Llandybie, aged 92, on 9 July 1799, possibly suggests that she may have been his unmarried sister as this person was probably born in $1706 .{ }^{57}$ Nothing more is known of William (J1)'s wife, except that she may have died in childbirth in 1707, which would neatly explain why William joined the Royal Navy in 1708 and why there was no provision for her at all in the Administrative Bond.

Walter (H)'s fifth son, Thomas (I), married in the 1670 s to Mary, ${ }^{58}$ and he is perhaps the person who died in Llandeilo Fawr in 1718 , aged about 73. He did have a son called Walter (K2), who was born in Llandeilo Fawr in 1681 (Table 2), and he was probably Thomas (I)'s first son, as he 
was named after his father, Walter (H). Walter (K2) may be the person who died in the parish on 22 October $1750 .^{59}$ In Llandybie, a Rees Morley (K) married Elizabeth David in 1701, and because they called their first son, who was born in 1702, Thomas, it implies that Rees (K)'s father had the same name and was possibly Thomas (I). However, if this is true, Rees (K) was married before the age of majority as his supposed elder brother was born in 1681 which places his birth to 1682 at the earliest.

The available evidence suggests that neither Walter (I2) nor Thomas (I) was the father of William (K1). This leaves William (I) as his likely father especially since William (K1) called his first son William, his second son, Thomas (L1), after his wife's father, and his third son, Walter (L1) suggesting that he may indeed have had an elder brother of the same name, but because the early parish registers have been lost, this cannot be verified. On balance, therefore, it seems likely that William (K1)'s father was William (I), the youngest son of Walter (H). It is believed that William (I) moved to Llandybie, perhaps at the time of his marriage about 1676, and he is probably the person who died there, aged about 70 , on 9 September $1717 .{ }^{60}$ However, following the usual naming convention, William (I)'s first son would have been called Walter (K1) after his father, and his second or third son, named William (K1) after himself. There is no record of this Walter (K1), who would have been born about 1679 and married about 1707, but if he existed, his first son would have been called William after his father, and his second or third son, after himself. It is possible that the William Morley who married Maria Rees, in Abergwili in 1728, and who died on 17 December 1739 at Llanarthney, ${ }^{61}$ may have been this first son and the Walter Morley (L2), born about 1712 (discussed above) may have been his second son.

\section{The Worcestershire Connection}

The previous account of the Morley genealogy disclosed that the progenitor of the Morleys in Carmarthenshire was a Walter Morley (G), a yeoman from Worcestershire, who had moved to Carmarthenshire at the end of the seventeenth century. ${ }^{62}$ According to the Golden Grove Book of Pedigrees he was the son of Thomas Morley (F1) and grandson of Thomas Morley (E) of Bayton in Worcestershire. ${ }^{63}$ Walter (G) was christened at St. Bartholomew's Church in Bayton (Figure 4) on 13 May 1566; his father's name was given as Thomas Morle. ${ }^{64}$ Walter (G) married Joyce Terry (Tyrry) also of the same county on 6 February 1592 in the same church in Bayton, $^{65}$ and he was therefore almost 26 years old at the time. Joyce's father was Thomas Terry (alias Tyrry/Tary) also of the same county. Their first two children were christened there also, their daughter Frances (H) on 13 December $1593^{66}$ who was probably named after Joyce's mother, and their son Thomas $(\mathrm{H})$ on 9 February $1595,{ }^{67}$ who was named after Walter (G)'s father. An earlier article also discloses that Walter $(\mathrm{G})$ had two further children, Walter $(\mathrm{H})$, who was named after himself, in this case, because the name of Joyce's father, Thomas, had already been used, and Joyce, who was probably called after Walter (G)'s mother although it is possible that she was called Frances also, in which case, the second daughter would have been named after his wife. It is not know whether the birth of Walter $(\mathrm{H})$ preceded or followed that of Joyce which is likely to have been in 1597 or 1599 . There is no record of the baptism of either Walter $(\mathrm{H})$ or Joyce in the parish registers at Bayton or in Worcestershire, suggesting that the family moved to Wales before they were born, possibly sometime after 1596. This information indicates that Joyce's mother was called Frances Terry, and Walter's mother was either Joyce or perhaps Francis Morley.

It is very unlikely that Walter Morley (G) was the first son of Thomas (F1), as this person would have been named after Thomas (E), his father. Unfortunately the extant parish registers at Bayton only start in $1564{ }^{68}$ and therefore there is no record of the birth of this putative son,
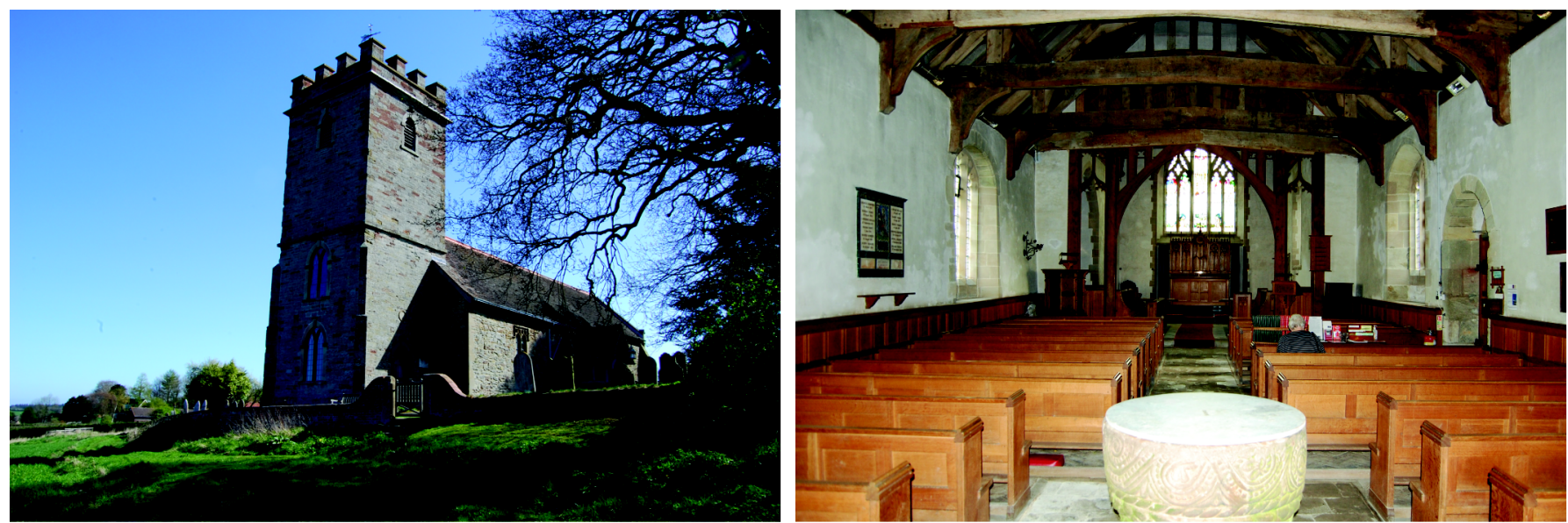

Figure 4. St. Bartholomew's Church in Bayton (Photographed by the author on 8 April 2011). 
Thomas Morley (G), because he was born before this date. The same argument applies to his marriage of his father, Thomas (F1), which again would be unrecorded for the same reason. Given that Walter $(G)$ was born in 1566, his putative elder brother, Thomas (G), would have been born at least two years earlier or longer if his father, Thomas (F1), had any intervening daughters. It is conceivable that this presumed first son may have died young, or he may have been the Thomas Morley who was alive in 1581, and described as the father of a Frances Morley, born on 10 December that year at Knighton Upon Teme, ${ }^{69}$ which lies only four miles from Bayton. However, for this to be true, Thomas (G) would have married by early 1581 , and his birth would have occurred about 1560 at the very latest, assuming he married at the age of majority. ${ }^{70}$ It is suggested that that Walter (G) moved his family to Wales in the mid 1590s following the death of his father at that time because his putative elder brother, Thomas (G), would have inherited most of his father's assets in Bayton including land, which Walter may have worked on as a farmer. It is likely that he also received an inheritance from his father which he then used to purchase a lease on the land in Llangathen, but why he chose Wales is unknown. That both Thomas $(\mathrm{G})$ and Walter $(\mathrm{G})$ called their first daughters, Frances, might indicate that this was the name of their mother, but this is probably a coincidence, as the first daughter was usually named after the wife's mother at this time, unless this daughter had died. Thomas (G)'s inferred date of birth places his father's marriage to about 1559 at the latest and his birth to about 1531 which fits in with the suggested date of the marriage of his father, Thomas (E) in 1529. However, it is not possible to deduce whether Thomas (F1) was Thomas (E)'s first son, as equally, he may have been the second or third son and named after himself. Confusingly, the parish registers in other parts of Worcestershire record several other Thomas Morleys who were alive in this era. For instance, another Thomas Morley (F3) married Lettis Weaver at All Saints Church, Worcester on 1 December $1571^{71}$ placing his birth to around 1543; he is perhaps the father of Ursula Morley, who was born at the same church on 24 July $1584 .^{72}$

One of the first references to the Morleys near Bayton in Worcestershire appears in a pedigree chart of the Dodington Family in The Visitation of Shropshire, ${ }^{73}$ which reveals that a Thomas Morley married Anne Dodington in the early sixteenth century. The Dodingtons took their name from the eponymous manor in the parish of Neen Savage in Shropshire where they resided. It seems that their family name was abbreviated in the early 1500s from de Dodington to Detton and this is the name which appears in the parish registers for Neen Savage, and as this lies only 3 miles from Bayton as the crow flies, it seems highly likely the person who married Anne Dodington was either Thomas Morley (E) or his son Thomas (F1). However, if this had been Thomas (F1), his son Walter (G) discussed above, would have called his second daughter after his mother, but because this child was called Joyce, not Anne, this almost certainly rules out the possibility that Thomas (F1) was Anne's husband. It is known that her grandfather, Robert Dodington (C), was married by 1476 to a Benedicta Morgan, who appears to have been a widow as her son, William, appears on the indenture of her marriage. ${ }^{74}$ Apparently, he died later without issue according to the pedigree chart and their first son, John Dodington, is likely to have been born around 1478, followed by his brother George (D) of whom nothing is known. John would have married Anna Broughton sometime later than 1499, after he had reached the age of majority. They had at least eight children; an only son and heir called Robert (E), and seven daughters, but the order of their births is not known as the pedigree chart referred to earlier is erroneous as it does not show the correct chronological order of births. This is clearly demonstrated for the case of the children of George Detton (F), the son and apparent heir of Robert (E), who was probably named after his father's uncle, George (D), as he had no brothers. These children are listed sequentially from left to right in the pedigree chart as: Thomas (b. 1580), George (b. 1587), Elizabeth (b. 1581), Beatrix (b. 1584), Anna (b. 1589), Mary (b. 1576), Francis (b. 1577) and Katherine (b. 1579) though their actual dates of christening shown in parenthesis do not lie in this order at all. ${ }^{75}$ The absence of a son named after his father, Robert (E), suggests that George's first son had died at birth or soon afterwards. George was married about a year or two before the birth of his first daughter Mary in 1576, and born in 1552 making him about 71 on the date of his death on 11 June $1619 .{ }^{76}$ None of Robert (E)'s other sons are called after his father, John, suggesting that there was probably another son with this name who died perhaps in 1548. This roughly places Robert (D)'s marriage to Maria Ketleby ${ }^{77}$ around 1546 and his birth to about 1518. He died on 14 November 1575 at Wheathill, Shropshire. ${ }^{78}$ The parish registers for Neen Savage show that a Mary Detton (presumed to be Robert's wife) died on 20 December $1595,{ }^{79}$ suggesting that she was born perhaps about 1525 and married therefore in 1546 at the age of majority.

Given that John Dodington married Anna Broughton probably about 1505, their first child was clearly a daughter, and she would have been named after Anna's mother, Jane Haven, ${ }^{80}$ if the usual naming convention had been followed, in the same way that their son Robert (E) was named after John's father, Robert (D). But a child of this name does not appear in the pedigree chart, nor does a daughter named Benedicta who would have been named after John's mother, suggesting that both these daughters, if they existed, had died early. The next daughter in line would have been named after John's wife, and indeed, there is listed a daughter called Anne who was probably their first surviving daughter. She would have been born perhaps around 1508, and married to Thomas Morley (E) about 1529 after she had reached the age of majority. Thomas was clearly a man of worth as Anne's father would not have allowed his first daughter to marry him. It is thought that Thomas (E) lived in Bayton at the time, and been born around 1501, but perhaps elsewhere. Unfortunately, there are no records of this Thomas Morley in the parish registers in this region of England despite the likelihood that he was probably still alive some years after records began in 1538. In the Golden Grove Books of Pedigrees, ${ }^{81}$ alluded to earlier, the authors Hugh Thomas ${ }^{82}$ and William Lewes ${ }^{83}$, assign a coat of arms to 


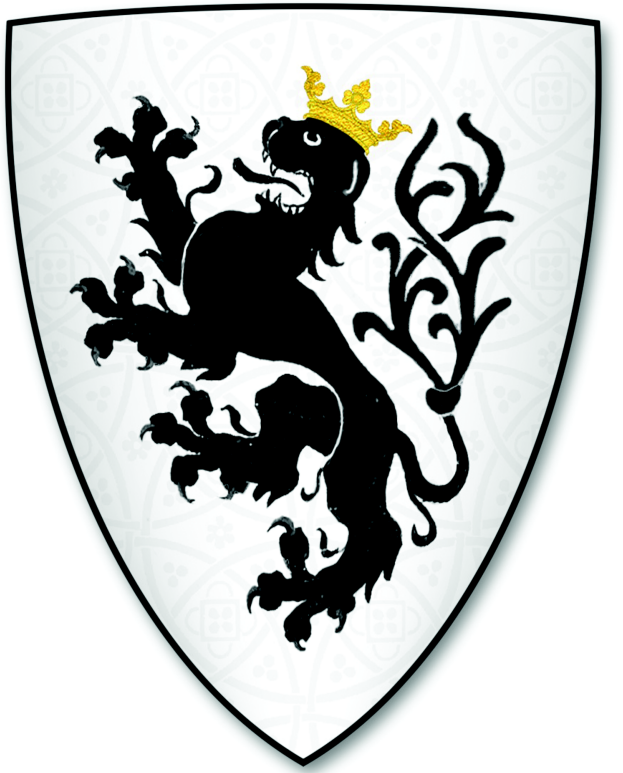

Figure 5. Norfolk Morleys Coat of Arms

Thomas Morley (E) which they describe as: Argent a lion rampant Sable crowned Or which appears to be identical to the coat of arms of the Barons Morley of Norfolk (Figure 5).

As previously reported, William Lewes (1652-1722), was a landowner and antiquary of Llwynderw, Carmarthenshire. He was a prominent genealogist and a competent writer in Welsh, Latin, and English having written some 25 pedigree volumes. Hugh Thomas (1673-1720) of Bloomsbury in London was the Deputy Herald to Garter King of Arms, and was also well versed in Welsh history having written a dissertation on the history of Brecknock in 1698. A letter sent to him by William Lewes in 1710-11 states that he had the sole right of registering Welsh genealogies apart from those relating to the counties of Cardigan and Radnor. ${ }^{84}$ This information suggests that the authors had convincing evidence to tie Thomas Morley (E) to the Morleys of Norfolk, implying that his family may have originated there. However, although the direct line of the Morleys in Norfolk died out with the death of Robert de Morley, the sixth baron, in $1442{ }^{85}$ at least one known cadet line of the family also existed for a time following a second marriage of Robert de Morley, the second baron. ${ }^{86}$ Another is thought to have descended in Lincolnshire from Thomas Morley, a putative third son of William, the first Lord Morley. ${ }^{87}$ It is thought that a third cadet line may also have existed in Morley, Derbyshire, as the family of a Richard de Morley, possessed identical arms to the Norfolk Morleys. ${ }^{88}$ If indeed Thomas Morley (E) was descended from this family, it is thought that the connection would have been through one of the cadet lines. An ongoing study ${ }^{89}$ has ruled out the possibility that this was the first cadet line as that also petered out, leaving the possible connection via the second, or third cadet line.

The parish registers in Worcestershire or Shropshire around this period record the marriages of several Morleys (Table 3). A Katherine Morley was married on 1 October 1564 at Bayton ${ }^{90}$ strongly indicating that this is where she and her parents lived at that time. It is thought that she was Thomas (F1)'s sister and born about 1538 or perhaps 1543 if she had married at the age of majority. A Margery Morley was married on 15 September 1560 at nearby Knighton-on-Teme, ${ }^{91}$ placing her birth to about 1534 . A William Morley (F1) was married on 4 June 1562 at Stanton Lacy $^{92}$ (about 16 miles NW of Bayton in Shropshire) placing his birth to about 1534. It is possible that both William and Margery were also related to Thomas (F) but this is by no means certain. The birth of an Elizabeth (Elyzabth) Morley is also recorded on 11 December 1554 in Chaddesley Corbett (about 16 miles east of Bayton), but her father was Robart Morley. ${ }^{93}$ The parish registers at Bayton also report the presence of a Humphrey Morley (Moorley) who was a contemporary of Walter (G). He had four children born there, three daughters born in 1607, 1610 and 1613 respectively and a son Humphrey, born in $1616 .{ }^{94}$ This places his marriage to 1606 at the latest and his birth to about 1578 , but there is no record of either of these events in Bayton, or indeed Worcestershire, suggesting that he moved there from elsewhere.

\section{Other Morleys in Worcestershire}

A cluster of Morleys was present in the hamlet of Berrow, in Worcestershire, ${ }^{95}$ during the sixteenth century as revealed by details in the wills of three yeomen with this surname. ${ }^{96}$ As this hamlet lies about 30 miles south of Bayton, it is conceivable that both families were related 
Table 3. Some Contemporaries and Descendants of Thomas Morley (E) in Worcestershire and Shropshire.

\begin{tabular}{|c|c|c|c|c|c|}
\hline Person & Dob & Dod & Notes/Event recorded ${ }^{b}$ & Place $^{c}$ & $\operatorname{Ref}^{d}$ \\
\hline Thomas Morley (E) & $1501 \mathrm{e}$ & & m. $1529 \mathrm{e}$ & Neen Savage & VS \\
\hline Richard Morley (E) & $1500-1510 \mathrm{e}$ & 1570 & death & Berrow & W \\
\hline Walter Morley (E) & $1516-1526 e$ & 1586 & death; m. Joane -- & Berrow & W \\
\hline William Morley (F2) & $<1549$ & & son of Richard (E) & Berrow & W \\
\hline Francis Morley (E) & 1517 e & & Suspected father of Johan, Francis, John and Anne Morley & Holt & IN \\
\hline Thomas Morley (F2) & 1559 e & 1612 & $\begin{array}{l}\text { death; son of Walter }(E) \text { ? } \\
\text { m. Anna Tewe, } 23 \text { Nov } 1573 \text { ? }\end{array}$ & $\begin{array}{r}\text { Berrow } \\
\text { Hanley Castle }\end{array}$ & $\begin{array}{l}\text { W } \\
\text { PR }\end{array}$ \\
\hline Thomas Morley (F1) & $1531 e$ & $1596 \mathrm{e}$ & Son of Thomas (E) m. Joyce-- 1558e & Bayton & GG \\
\hline Katherine Morley & $1538 \mathrm{e}$ & & m. Christelle Payten 1 Oct 1564 & Bayton & PR \\
\hline William Morley (F1) & $1534 \mathrm{e}$ & & m. Ju'an (Joanne) Prince 4 June 1562 & Stanton Lacy & BMI \\
\hline Thomas Morley (G) & $1560 \mathrm{e}$ & & m. 1581e; wife not recorded; dau. Francis b. 10 Dec 1581 & Knighton Upon Teme & PR \\
\hline Walter Morley (G) & 13 May 1566 & & $\begin{array}{l}\text { son of Thomas (F1) } \\
\text { m. Joyce Terry } 6 \text { Feb } 1592\end{array}$ & Bayton & $\begin{array}{l}\text { PR } \\
\text { PR }\end{array}$ \\
\hline Frances Morley $(\mathrm{H})$ & 13 Dec 1593 & & dau. of Walter (G) & Bayton & PR \\
\hline Thomas Morley $(\mathrm{H})$ & 9 Feb 1595 & & son of Walter $(\mathrm{G})$ & Bayton & PR \\
\hline Margery Morley & 1534 & & m. Rychard Pennell 15 Sept 1560 & Knighton Upon Teme & PR \\
\hline Gyles Morley & 30 May 1540 & & father not recorded & Saint Helen & PR \\
\hline Thomas Morley (F3) & $1543 e$ & & m. Lettuce Weaver, 1 Dec 1571 & Worcester & PR \\
\hline Elyzabth Morley & 11 Dec 1554 & & dau. of Robart Morley & Chaddesley Corbett & PR \\
\hline
\end{tabular}

a Date of birth (DoB) taken either from the parish registers, IGI, or estimated (e) assuming that men married at 28 and women at 26 (see text); Date of death (Dod) taken from their wills. ${ }^{\mathbf{b}}$ Key: $\mathrm{m}$. = marriage; dau = daughter. ${ }^{\mathrm{C}}$ Place of birth, marriage or residence. ${ }^{\mathrm{d}}$ Source of data: VS $=$ Visitation of Shropshire; GG $=$ Golden Grove Book of Pedigrees; W = Will (see text); IN = Inferred and estimated from the Dob of their children/grandchildren; PR=Parish Registers; BMI = Boyd's Marriage Indexes, 1538-1850.

(Table 3). Unfortunately, there no existing parish records for Berrow earlier than 1611 which means that no other records exist for any of the three yeomen discussed here or their immediate families. ${ }^{97}$

Chronologically, in the first will, a Richard Morley (E), who died on 23 January 1570, leaves farm implements to his son, William (F1), and appoints his wife Jane as executrix with a Walter Morley (E), Robert Morley (E) and Thomas Alderne named as his overseers. ${ }^{98}$ In a separate annex attached to the will, his son William (F) is charged with administrating his father's goods, chattels and debts. No other children are mentioned in the will or in the bond suggesting that he was the only son. He was therefore at least 21 years old at this time, and was born sometime before 1549. Life expectancy in this era is not known with any certainty at all, and in 1600-1699 it was only about 36 years at birth, but once infant mortality and children's fatal illnesses are removed from the available data, it rises to around approximately 61years, ${ }^{99}$ though gentlemen such as physicians enjoyed a longer lifespan of ranging from 58-76 during this period. ${ }^{100}$ Given that yeoman were generally healthy outdoor people, it is likely that they too would have enjoyed a fairly long life and reached 60 if not the biblical age of three score years and ten. If so, Richard (E) would have been born during the period $1500-1510$ if he had indeed reached the average lifespan of 60-70 years in the year of his death.

One of the overseers, ${ }^{101}$ Walter Morley (E), is almost certainly the same person who died later on 21 January 1586 also at Berrow, but his will has been lost. However, two separate annexes to the will survive, one showing a list of his assets, with Robert Morley (E) and Richard Beale named as overseers. ${ }^{102}$ A second document names his wife Joane as the administratrix of his goods, chattels and debts, with a Thomas Morley (F2) also of Berrow, included in this obligation. Assuming that Walter $(\mathrm{E})$ reached the expected life span of 60-70 years he would have been born around 15161526. Thomas (F2) was possibly his son, as he seems to fulfil the same obligations as Richard (E)'s son, William (F1), in the latter's will, but this is not stated. Thomas Morley (F2), who is described as a yeoman, died in Berrow in 1612, ${ }^{103}$ and he may have been the person who married Anna Tewe on 23 November 1573 at Hanley Castle near Worcester, ${ }^{104}$ which only lies about 6 miles from Berrow as the crow flies. Assuming that Thomas (F2) reached the expected life span, he would have been born in 1542 at the earliest, suggesting that his supposed father, Walter $(\mathrm{E})$, was born around 1516. However, one important caveat should be mentioned: it is not possible in this period to deduce the name of the father from the name of the son with any certainty because of the high infant and children mortality rates. For example, it has been estimated from parish records that infant mortality (death during the first year of life) was approximately 140 out of 1000 live births at this time. Furthermore, diseases such as dysentery, scarlet fever, whooping cough, influenza, smallpox, and pneumonia killed perhaps 30\% of England's children before the age of $15 .{ }^{105}$

Robert Morley (E), died in 1593, also in Berrow, with Thomas Morley (F2), and also John Good given as the executors of his will. ${ }^{106}$ He had five surviving children named in sequence: Mary, William (F2), John, Richard and Robert (G1). He left his son Richard the sum of $£ 44$ to be paid to him at the age of 23 years, indicating that Richard had not yet reached that age at the time his will was written in 1592, implying that he was born therefore after 1569. None of Robert (E)'s other four children had any such conditions attached to their inheritance implying that they were at least 21 years old in 1592, and born therefore before 1571. Assuming that Robert (E) lived a full life, he would have been born between 
1523 and 1533 and married his wife, Elizabeth, about 1555. William (F2) is thought to have been his first surviving son as he is named first and he appears to inherit his father's livestock and equipment, with his mother Elizabeth inheriting the property until her death when presumably it would be transferred to him. All of Robert (E)'s other children received money except Robert (G1), who inherited lands and a property called Sandhurste from his father. Robert (G1) is possibly the person who married Elizabeth Baxter on 12 June 1597 at Bushley in Worcestershire, ${ }^{107}$ implying that he was born around 1569. If William (F2) was indeed Robert (E)'s first son, then his father was called William also, but it is also entirely possible that there was an earlier son who had died. Another William Morley (G) was alive in Berrow at this time as he had several children who were born between 1614 and $1621{ }^{108}$ placing his birth to perhaps 1585 . He was possibly the son of one of Robert (E)'s sons, perhaps William (F2). Either William (F2) or (G) was probably the person who died in Berrow in $1636 .{ }^{109}$ Descendants of the family were still present in Berrow in 1703. ${ }^{110}$

The IGI Family History Library reports the christenings of a further cluster of Morleys at Holt in Worcestershire. Johan (Joanne) Morley was christened on 2 July 1547, Francis Morley (F) on 15 June 1550, John Morley on 14 May 1551, and Anne Morley on 21 December $1552 .{ }^{111}$ No reference source is given for this IGI data but the precise dates quoted suggest that this information may be reliable. Their father is unknown but his name can be tentatively identified in principle by analysing the names of some his grandchildren who were also born there. Francis ( $F$ ) had seven children at Holt born between 1576 and 1591. He would have married at the earliest in June 1571 when he had reached the age of majority but before April 1575. The first three in chronological order were: Robert (G2) born on 25 January $1576,{ }^{112}$ John born on 15 September 1578, and Christian born on 10 April 1580. However, if the usual naming convention had applied, he should have called his third son after himself, i.e. Francis (G). That he did not, and given that his seventh child born in 1591 was called Francis (H), suggests that he had an earlier son called Francis (G), probably born around 1574, who had died before his christening. If true, Robert's first surviving son, would have been named after his wife's father while his second surviving son would have been named possibly after a brother, as his own name had already been used. All in all, this implies that the father of the Morley family in Holt was a Francis Morley (E) who would have married by 1545 and been born about 1517, making him a contemporary of the Morleys in Berrow.

It is thought that the three Morleys in Berrow, Richard $(\mathrm{E})$, Walter $(\mathrm{E})$, and Robert $(\mathrm{E})$ were closely related, but assuming they all enjoyed roughly the same life span, the gap between the first and third individuals of 23 years is too large for them to have been brothers. However, there is no guarantee at all that any of them reached roughly the same age, and if Richard (E) had died at 60, and the others at 70, then they may well have been brothers with a gap of only 13 years between all three. Unfortunately, it is not possible to deduce the name of their common father from the names of their sons for reasons given earlier. Nevertheless, because both Richard (E)'s and Robert (E)'s first surviving sons are thought to be named William (F1) and (F2) respectively, it is possible that father of the three Morleys in Berrow was a William Morley. It is entirely possible that Thomas Morley (E) of Bayton, and the putative Francis Morley (E) of Holt, were related to these Morleys, but there is no evidence to support this conjecture, especially as the surname appears to have been fairly common in the adjacent counties. For example, in the adjacent county of Staffordshire, there are numerous references to families named Morley in the parish records; ${ }^{113}$ at Burton upon Trent, alone, there are over 200 references to Morleys recorded between 1538 and 1600 . A similar picture emerges for the population of Morleys in Derbyshire and Herefordshire, and the name also occurs, but to a lesser extent, in Gloucestershire and Shropshire also. Notwithstanding this difficulty, it does seem that the Morleys in Bayton and Berrow were all yeomen and all farmed on the western side of the county.

That Thomas (F1) called his son Walter (G) suggests that this may have been a well-used family name. But as his father was Thomas (E), Thomas (F1)'s first son should have borne the same name, Thomas (G), implying that his known son Walter (G) was named after his wife's father. The possibility that Thomas (F1)'s father-in-law was also called Thomas cannot be discounted, and in these circumstances, because this name had already been used, his next son would have been called after an unknown brother of Thomas (F1). Furthermore, if the putative Thomas (G) was Thomas (F1)'s first son, the six year gap between his supposed birth in 1560 and the birth of Walter in 1566 leaves time for a second son who may have died. Under these circumstances, Walter (G) would have been the third son. If either of these two scenarios is correct, Walter (G) was almost certainly called after one of Thomas (F1)'s brothers, who may have been called in turn, after Walter (E). The limited information available suggests that Thomas (E) was the father of several children including Thomas (F1) and Katherine Morley, who was almost certainly born in Bayton, as it was the custom at this time to marry in the bride's parish. This implies that William Morley (F1) may have been from Bayton also, but Margery Morley was probably not a sibling as she was married in Knighton Upon Teme. It is not possible to decide the name of Thomas (E)'s father with any certainty as he may have had several other sons who died. However, as indicated earlier, Thomas (E) was almost certainly a wealthy man or landowner as John Dodington would not have allowed his first daughter to marry beneath herself. As Thomas (E) was born around 1501, his father, in turn, would have married about 1500 at the latest, and although it is possible that Thomas (E) was his first son and inherited his estate this is by no means certain. If this were so, however, his father was called Thomas (D), who would have been born around 1472 in Worcestershire or perhaps one of the contiguous counties. A family of this name is recorded in Ashperton, Herefordshire, where a Thomas Morelay, the elder, was a collector of a tax in that county in $1440,{ }^{114}$ indicating that he had a son called Thomas 
also who would have been a contemporary of the putative Thomas (D). However, the possible connection of the Morleys of Bayton to those in Norfolk remains elusive and unproven despite the evidence provided by the Golden Grove Books of Pedigrees discussed earlier.

\section{Conclusion}

There seems little doubt that the Morleys found in the Vale of Neath in the eighteenth century originated in Worcestershire. The progenitor of this family was Walter Morley (G), who migrated to Llangathen in the late 1590s and probably leased land there as part of an inheritance from his father Thomas Morley (F1). Walter (G)'s family expanded considerably over the next hundred years and it is thought that his putative grandson William (K1) moved to the Vale of Neath in the early eighteenth century. Although it has been proposed that the Morleys originated in Norfolk, no concrete evidence has yet been uncovered to verify this contention.

\section{References}

1. Morley, John O. (2013) The Rise of the Herberts of Raglan: the Norfolk Connection, The Monmouthshire Antiquary, Vol. XXIX, 27-45.

2. Morley, John O. (2010) Reflections on the Role of the Sussex Ironmasters in Elizabethan Glamorgan, Journal of Glamorgan History (Morgannwg), Vol. LIV, 5-43.

3. Morley, John O. (2010) Origins of the Morleys in Carmarthenshire, 1500-1800, Carmarthenshire Antiquary, Vol. XLVI, 57-67. Morley, John O. (2013) The Origins of the Morleys in England and their Early Appearance in Wales, Annals of Genealogical Research (henceforth AGR), Vol. 9, No. 1, 33-37, http://www.genlit.org/agr/view article.php?id=51

4. 1841 and 1901 National Census data, findmypast, https://www.findmypast.co.uk/i and FamilySearch, https://www.familysearch.org.

5. Ancestors, http://www.byub.org/ancestors/records/vital/extra5.html; UK Naming Conventions in Familyhistoryalive, http://www.familyhistoryalive.com/NamingConventions.html; British Naming Conventions in Research Wiki, https://family search.org/wiki/en/British_Naming_Conventions.

6. https://en.wikipedia.org/wiki/Welsh_surnames.

7. Morley, John O. (2012) Genealogy of the Morleys in South Wales: Glamorgan and the Vale of Neath from 1700 to 1800, AGR, Vol. 8, No. 1, 1-30; http://www.genlit. org/agr/viewarticle.php?id=37.

8. Lewis, E. D. (1959) The Rhondda Valleys. A Study in Industrial Development, 1800 to the Present Day, Phoenix House, London.

9. To distinguish between members of the Morley family with the same forename the standard Generation Grid has been used. Currer-Briggs, Noel and Gambier, Royston. (1981) Debrett's Guide to Tracing Your Ancestry, Webb and Bower, London, p.189 which assigns the following letters to the date of birth: A 1380-1409; B 14101439; C 1440-1469; D 1470-1499; E 1500-1529; F 1530-1559; G 1560-1589; H 15901619; I 1620-1649; J 1650-1679; K 1680-1709; L 1710-1739; M 1740-1769; N 17701799; O 1800-1829; P 1830-1859; Q 1860-1889; R 1890-1919; S 1920-1949; T 19501979; U 1980-2009. In this system, men are allocated numbers 1-49, and women numbers $50-99$.

10. It is thought that she was Maria Morley who was baptized on 21 October 1720 at Llantilio Crossenny, Monmouthshire. She was the reputed daughter of Walter Morley of Llandilo Fawr, Carmarthenshire and Elizabeth David who had died prior to this baptism while in the employment of Henry Herbert at Llantilio Crossenny. I thank Mr Richard Davis for this information..

11. Wrigley, E. A. and Schofield, R.S. (1983) English Population History from Family Reconstitution: Summary Results 1600-1799, Population Studies, 37 (2), 157-184. See also: Lee, R. D. and Schofield, R. S. (1981) British Population in the Eighteenth Century in The Economic History of Britain since 1700, eds. Floud, R. and McClosky, D. Vol. 1: 1700-1800, Cambridge University Press, pp. 17-35.

12. Shepard, Alexandra, (2011) Family and Household in The Elizabethan World, ed. Doran, Susan and Jones, Norman, Routledge, Oxford, Chapter 21, pp. 359-370.

13. Morley, op. cit., AGR, 9-12

14. The age of marriage under Life and Times/The Family, Internet Shakespeare Editions, http://internetshakespeare.uvic.ca/Library/SLT/society/family/marriage.html.

15. The George B. Hammond Papers, Transcript of the register of births, marriages and deaths for Cadoxton Juxta Neath, Llantwit Juxta Neath and the town of Neath, 1653-1679, Ref.: NAS GBH 1/4.

16. The George B. Hammond Papers, Transcript of the accounts of the churchwardens and overseers of the parish and town of Neath, Glamorgan, 1674-1700, Ref.: NAS GBH $1 / 4$.

17. Phillips, D. Rhys. (1925) The History of the Vale of Neath, Swansea, Appendix II, pp. 648-655.
18. Parkinson, E. (ed.) (1994) The Glamorgan Hearth Tax Assessment of 1670, South Wales Record Society, Publication No. 10, Cardiff; Welsh Journals Online, http:// welshjournals.llgc.org.uk/browse/listarticles/lgc-id:1044290/llgc-id:1044716.

19. Parish register for St. Catwg's Church, Cadoxton Juxta Neath: Baptisms, Marriages, and Burial indexes 1738 to 1924 .

20. Parish registers for Llantwit Juxta Neath; Baptisms, Marriages, and Burial index 1695 to 1896.

21. Parish registers for Neath; Baptism, Marriage, and Burial index 1692-1793.

22. WGPR, FamilySearch, https://familysearch.org/ark:/61903/1:1:VFH9-R8C, accessed 24 April 2016, Thomas John, 1772; Burial, Cadoxton-J-Neath, Glamorgan, Wales, Glamorgan Family History Society, Cardiff.

23. WGPR, FamilySearch, https://familysearch.org/ark:/61903/1:1:VFH9-RRH, accessed 26 May 2016, Elinor John, 1773; Burial, Cadoxton-J-Neath, Glamorgan, Wales, Glamorgan Family History Society, Cardiff.

24. National Library of Wales (hereafter NLW). Will of Thomas Bevan (Beavan) of Cadoxton Juxta Neath (23 June 1730; probate granted 31 June 1731), St. David's Probate Records 1556-1858, http://hdl.handle.net/10107/728765.

25. WGPR, FamilySearch (https://familysearch.org/ark:/61903/1:1:VFH5-ZN5, accessed 3 June 2016, William Morley, 1758; Baptism, Llantwit-J-Neath, Glamorgan, Wales, Glamorgan Family History Society, Cardiff.

26. Wales, Glamorganshire, Parish Registers, 1538-1912, FamilySearch, https://familysearch.org/ark:/61903/1:1:KCB6-9Y5, accessed 3 June 2016, Evan Morley, 27 Jun 1760, Baptism; from Parish Records Collection 1538-2005, findmypast, http://www. findmypast.com.

27. Based on a map published by West Glamorgan Archive Service, Civic Centre, Oystermouth Rd, Swansea SA1 3SN, https://www.swansea.gov.uk > Ancientparishes-in-West-Glamorgan > pdf.

28. Wales, Carmarthenshire, Parish Registers, 1538-1912, (hereafter WCPR), FamilySearch, https://familysearch.org/ark:/61903/1:1:KCLK-D46, accessed 20 May 2016, Mary Morley, 13 Nov 1801, Burial; from Parish Records Collection 15382005, findmypast, http://www.findmypast.com.

29. Morley, AGR, Vol. 8, 16-17.

30. Wales, Glamorganshire, Parish Registers, 1538-1912, FamilySearch, https:/familysearch.org/ark:/61903/1:1:KCB6-396, accessed 7 June 2016, William Hopkin and Sarah David, 28 Apr 1742, Marriage; from Parish Records Collection 1538-2005, findmypast, http://www.findmypast.com.

31. WGPR, FamilySearch, https://familysearch.org/ark:/61903/1:1:VFZT-15X, accessed 5 December 2014, Mary Hopkin, 1752; Burial, Cadoxton-J-Neath, Glamorgan, Wales, Glamorgan Family History Society, Cardiff.

32. Morley, op. cit., $A G R, 1-30$.

33. Morley, op. cit., Carm. Antiq., 57-67. Morley, op. cit., AGR, Vol. 9, 33-37, http://www. genlit.org/agr/viewarticle.php?id=51.

34. Lewes, William and Thomas, Hugh. ( 1703) The Golden Grove Books of Pedigrees, Vol. 2, p. 216 (G1164), held at the Carmarthenshire Archive Service, Parc Myrddin, Richmond Terrace, Carmarthen, SA31 1HQ, UK.

35. The Bainbridge/Brigstock Typescript or Manuscript, Society of Genealogists; see Welsh Registers, Vol. 13 (WS/R 80), Accession No. 67594c. [Llandilo Fawr: Christenings 1720-24, 1732-34 (extracts), 1679-84/85, 1730-57, 1765-76 (Bishop's Transcripts), Marriages 1683-1722 (extracts), 1732, 1738-40, 1745-49, 1754-59, 1762, 1767-69, Births 1679-1723 (extracts), 1684, 1730-79 (Bishop's Transcripts)], http:// www.sog.org.uk/index.shtml.

36. NLW. Will of Walter Morley of Llangathen, dated 12 May 1640; probate granted 3 July 1643; St. David's Probate Records 1556-1858, http://hdl.handle.net/10107/ 431504. 
37. NLW. Will of John Lewis Morgan of Llangadock (28 January 1649; probate granted 20 March 1649), St. David's Probate Records 1556-1858, http://hdl.handle.net/ $10107 / 334125$

38. NLW. See the entry for Thomas Morley in the Dynevor Collection A, No. A31 (13 July 1637).

39. Lee and Schofield, op. cit., pp. 26-27. Wrigley and Schofield, op. cit., 172-175.

40. The National Archives (hereafter TNA). Chancery Records. Morley v Search. C 22/125/ 5 (17 January 1665). See also: TNA. Chancery Records. Morley v Search. C 6/23/72

41. Galley, C., Garrett, E., Davies, R. and Reid, A. (2011) Living Same-Name Siblings and British Historical Demography, Local Population Studies, 86. 15-36, http://www. localpopulationstudies.org.uk/PDF/LPS86/LPS\%2086\%20Spring\%20Galley.pdf Stone, L. (1979) The family, sex and marriage in England 1500-1800, London, p. 257. Smith-Bannister, S. (1997) Names and naming patterns in England 1538-1700, Oxford, pp. 71-4.

42. Deeds of the Vaughans of Golden Grove and Related Families, 1313-1811, in the Cawdor Vaughan Muniments, Vol. 1, p. 114, Item 1/1, Carmarthenshire Archives.

43. NLW. Administrative Bond and Inventory of Rice Morley of Llandeilo Faw Carmarthen, Probate granted 1710; St. David's Probate Records, 1556-185, http:// hdl.handle.net/10107/729698.

44. Jones, op. cit., p. 153

45. Morley, op. cit., Carm. Antiq., 57-67; Morley, op. cit., AGR, Vol. 9, 33-37.

46. The National Archives, The Hearth Tax Assessment for Carmarthenshire 1670; Ref: E179/220/128.

47. Llandybie Parish Registers; Ref.: CPR/16/1/1.

48. NLW. Administrative Bond: Elizabeth Griffith, widow of Llandeilo Fawr in Carmarthenshire, 8 December 1697; St. David's Probate Records 1556-1858, http://hdl.handle.net/10107/639673.

49. Morley, John O. (2012) Addendum: Genealogy of the Morleys in South Wales: Glamorgan and the Vale of Neath from 1700 to 1800, AGR, Vol. 8, No. 1, Supplementary File pp. 1-5, http://www.genlit.org/agr/viewarticle.php?id=37.

50. NLW. Administrative Bond: William Morley of Llangyfelach, Glamorgan, dated 29 March 1712; St. David's Probate Records 1556-1858, http://hdl.handle.net/10107/ 245893

51. The Law Dictionary Featuring Black's Law Dictionary Free Online Legal Dictionary 2nd Ed., http://thelawdictionary.org/infant/.

52. NLW. Will of Edith Griffith of Llandeilo Fawr, Carmarthen, Spinster (2 October 1703), St. David's Probate Records 1556-1858, http://hdl.handle.net/10107/700675.

53. WCPR, FamilySearch, https://familysearch.org/ark:/61903/1:1:KCLC-JXM, accessed 21 April 2016, Anna Williams, 18 Feb 1730, Burial; from Parish Records Collection 15382005, findmypast, http://www.findmypast.com

54. WCPR, Gabriel Lewis, 1670, Marriage; from Parish Records Collection 1538-2005, findmypast, http://www.findmypast.com

55. WCPR, FamilySearch, https://familysearch.org/ark:/61903/1:1:KCLC-X6L, accessed 12 April 2016, Gulielmus Morley and Maria John, 15 Oct 1721, Marriage; from Parish Records Collection 1538-2005, findmypast, http://www.findmypast.com.

56. WCPR, Anna Morley, 1726, Baptism; from Parish Records Collection 1538-2005, findmypast, http://www.findmypast.com.

57. WCPR, FamilySearch, https://familysearch.org/ark:/61903/1:1:KCLZ-M1G, accessed 31 May 2016, Elizabeth Morley, 09 Jul 1799, Burial; from Parish Records Collection 1538-2005, findmypast, http://www.findmypast.com.

58. NLW. See the entry for Thomas Morley in the Eaton Evans and Williams Collection 2 (A), No.: 2871 (11 Sept. 1700).

59. WCPR FamilySearch, https://familysearch.org/ark:/61903/1:1:KCLJ-BGD, accessed 28 April 2016, Walter Morley, 22 Oct 1750, Burial; from Parish Records Collection 1538 2005, findmypast, http://www.findmypast.com.

60. WCPR, FamilySearch, https://familysearch.org/ark:/61903/1:1:KCLC-6G3, accessed 15 April 2016, Gulielmus Morley, 09 Sep 1717, Burial; from Parish Records Collection 1538-2005, findmypast, http://www.findmypast.com.

61. WCPR, FamilySearch, https://familysearch.org/ark:/61903/1:1:KCLN-7MR, accessed 20 April 2016, William Morley, 17 Dec 1739, Burial; from Parish Records Collection 1538-2005, findmypast, http://www.findmypast.com.

62. Morley, op. cit., Carm. Antiq., 59-61.

63. Lewes and Thomas, op. cit., Vol. 2, p. 216 (G1164)

64. England Births and Christenings, 1538-1975, (hereafter EBC), FamilySearch, https:// familysearch.org/ark:/61903/1:1:NYKP-CGC, accessed 6 December 2014, Walter Morle, 13 May 1566.

65. England Marriages, 1538-1973, (hereafter EM), FamilySearch, https://familysearch org/ark:/61903/1:1:NKSJ-C35, accessed 10 December 2014, Walter Morley and Joiesam Tyrry, 06 Feb 1592

66. EBC, FamilySearch, https://familysearch.org/ark:/61903/1:1:J3SP-9FZ, accessed 6 December 2014, Walter Morley in entry for Fraunces Morley, 13 Dec 1593.
67. EBC, FamilySearch, https://familysearch.org/ark:/61903/1:1:JMZ6-DM2, accessed 6 December 2014, Watter Morley in entry for Thomas Morley, 09 Feb 1595.

68. FamilySearch, https://familysearch.org/search/record.

69. EBC, FamilySearch, https://familysearch.org/ark:/61903/1:1:NLFR-B7F, accessed 30 December 2014, Frances Morley, 10 Dec 1581.

70. See for example, James, T. E. (1960) The Age of Majority', in The American Journal of Legal History, Vol. 4, No. 1, 22-33.

71. EM, FamilySearch, https://familysearch.org/ark:/61903/1:1:NVZL-RP5, accessed 10 December 2014, Tho. Morlye and Lettis Wever, 01 Dec 1571

72. EBC, FamilySearch, https://familysearch.org/ark:/61903/1:1:J3M6-PJG, accessed 6 December 2014, Vrsula Morley, 24 Jul 1584

73. Tresswell, Robert and Vincent, Augustine. (1889) The Visitation of Shropshire, Taken in the Year 1623, edited by Grazebrook, George and Rylands, John Paul, London, Part 1, p. 166, https://archive.org/stream/visitationshrop00britgoog\#page/n220/ mode/1up

74. Tresswell and Vincent, op. cit., Part 1, p. 166. A footnote states 'An Indenture of Mariage betwixt John Botrell Lorde of Aston and Robert Dodynington \& Benedict his wife \& William sone to Benedicte Decimo sexto' of E. 4.

75. FamilySearch, https://familysearch.org/search/record.

76. Find A Grave Index, FamilySearch. http://FamilySearch.org, accessed 11 September 2019. Citing index and images. Find a Grave, http://www.findagrave.com, accessed 24 September 2019, memorial page for George Detton (1552-11 Jun 1619). Find A Grave Memorial no. 130909626, Saint Mary Churchyard, Neen Savage, Shropshire, England

77. Tresswell and Vincent, op. cit., Part 2, p. 288 (Pedigree of Ketleby of Steeple).

78. Community Trees, FamilySearch, https://familysearch.org/ark:/61903/2:2:3ZD7-KCG accessed 25 May 2018

79. England Deaths and Burials, 1538-1991, FamilySearch, https://familysearch.org/ark: 61903/1:1:J8NJ-7Z7, accessed 24 December 2014; Flagg, Ernest. (1926) Genealogical Notes on the Founding of New England: My Ancestors Part in that Undertaking, Genealogical Publishing Com, pp. 313-315, https://books.google.co.uk/books?id= zPnD0kvrLf8C\&pg=PA313\#v=onepage\&q\&f=false.

80. Tresswell and Vincent, op. cit., Part 1, p. 83 (Pedigree of Broughton of Broughton and Henley).

81. Lewes and Thomas, op. cit., Vol. 2, p. 216 (G1164)

82. Jenkins, Robert T. Welsh Biography Online, http://wbo.llgc.org.uk/en/s-THOM-HUG1673.html.

83. Jones, Francis. Welsh Biography Online, http://wbo.llgc.org.uk/en/s-LEWE-WIL-1652. htm.

84. Cat. of Welsh MSS. in the British Museum, Item ii (full index), quoted under the entry for 'Hugh Thomas' in Welsh Biography Online.

85. Cokayne, George Edward and Stokes, Ethel. (1936) Morley, in The Complete Peerage, or A History of the House of Lords and all its Members from the Earliest Times (hereafter TCP), eds. Doubleday, H. A. and Lord Howard de Walden, London, Vol. 9, p. 209-234. Richardson, Douglas (2011) Plantagenet Ancestry: A Study in Colonial and Medieval Families, ed. K. G. Everingham (Second edition), pp. 552-559. Morley, AGR,Vol. 9, 8-14, http://www.genlit.org/agr/viewarticle.php?id=51.

86. Banks T. C. (1808) The Dormant and Extinct Baronage of England (hereafter DEBE), London, Vol. 2, pp. 357-360, https://books.google.co.uk/books?id= p9RAAQAAMAAJ\&pg $=$ PR3\&lpg $=P R 3 \& d q=T .+C .+$ Banks,+ The + Dormant + and + Extinct+Baronage+of+England, + Volume +2 .

87. Larken A. S. (1908) Lincolnshire Pedigrees, London, ed. A.R. Maddison, Vol. 2, pp. 690-92, https://archive.org/stream/lincolnshireped01larkgoog\#page/n319/mode/ 2up.

88. Lysons, Daniel and Lysons, Samuel. (1817) General History of Derbyshire: Families extinct before the Time of the Heralds' Visitations, in Magna Britannia, Vol. 5 , Derbyshire London, p. cvii, https://books.google.co.uk/books?id= qUBaAAAAcAAJ\&pg=PR107.

89. Morley, John O. Tracing the Descendants of the Norfolk Morleys.

90. EM, FamilySearch, https://familysearch.org/ark:/61903/1:1:NKSJ-C48, accessed 10 December 2014, Christelle Payten and Katherine Morley, 01 Oct 1564

91. EM, FamilySearch, https:/familysearch.org/ark:/61903/1:1:NVZ2-8ZP, accessed 10 December 2014, Rychard Pennell and Margery Morleye, 15 Sep 1560.

92. Boyd's Marriage Indexes, 1538-1850, Society of Genealogists, Findmypast, https:// search.findmypast.co.uk/record?id=GBPRS/M/753353954/1.

93. EBC, FamilySearch, https://familysearch.org/ark:/61903/1:1:JMZ6-357, accessed 6 December 2014, Elyzabth Morley, birth 11 Dec 1554

94. FamilySearch, https://familysearch.org/search/record.

95. Parishes: Berrow, in A History of the County of Worcester: Volume 3 (London, 1913) pp. 257-261. British History Online, http://www.british-history.ac.uk/vch/worcs/vol3/ pp257-261, accessed 14 May 2018. 
96. A Calendar of Wills and Administrations Registered in the Consistory Court of the Bishop of Worcester, ed. Fry, Edward Alexander [hereafter CWAW] (1904) Vol. 1 1451-1600, London, https://archive.org/stream/calendarofwillsa01worcuoft\#; CWAW, (1910) Vol. 2, 1601-1652, London, https://archive.org/stream/ calendarofwillsa40worc\#.

97. FamilySearch, https://familysearch.org/search/record.

98. Will of Richard Morley of Berowe, Worcestershire, dated 21 January 1570, Archive Collections Services, Worcestershire County Council; CWAW, Vol.1, p. 219, https:// archive.org/stream/calendarofwillsa01worcuoft\#page/219.

99. Johansson, S. Ryan (2010) Medics, Monarchs and Mortality, 1600-1800: Origins of the Knowledge-Driven Health Transition in Europe, University of Oxford, Discussion Papers in Economic and Social History, No. 85, p. 15, https://www.nuff.ox.ac.uk/ economics/history/Paper85/johansson85.pdf.

100. J. B. Griffin, J. B. (2008) Changing life expectancy throughout history, Journal of the Royal Society of Medicine, 101 (12),577 [https://www.ncbi.n/m.nih.gov/pmc/articles/ PMC2625386/].

101. Williams, Edward V. (1841) The Law of Executors and Administrators, Philadelphia, Vol.1, pp. 136-7, https://books.google.co.uk/books?id=I1 cWuGr-nUC\&pg=PA136.

102. Fragment of The Will of Walter Morley of Berowe, Worcestershire, dated 23 January 1586, Archive Collections Services, Worcestershire County Council; CWAW, Vol. 1 pp. 54, 306, 367, https://archive.org/stream/calendarofwillsa01worcuoft\#page/54.
103. CWAW, Vol. 2, p. 54, https://archive.org/stream/calendarofwillsa40worc\#page/n63. 104. EM, FamilySearch, https://familysearch.org/ark:/61903/1:1:NKS6-CQZ, accessed 10 December 2014, Thomas Morley and Annam Tewe, 23 Nov 1573.

105. Lynda Payne, Health in England (16th-18th c.), in Children and Youth in History, Item \#166, http://chnm.gmu.edu/cyh/items/show/166, accessed August 14, 2018.

106. TNA, Will of Robert Morley, Yeoman of Berrow, Worcestershire, written on 2 September 1592 but dated 12 February, 1593, Cat. Ref.: PROB 11/81.

107. EM, FamilySearch, https://familysearch.org/ark:/61903/1:1:NLXK-L2B, accessed 10 December 2014), Robert Morley and Elizabeth Baxter, 12 Jun 1597.

108. EBC, FamilySearch, https://familysearch.org

109. CWAW, Vol. 2 p. 219, p. 160, https://archive.org/stream/calendarofwillsa40worc\# page/n169.

110. Grazebrook, H. Sidney. (1873) The Heraldry of Worcestershire, London, Vol. II, p. 727 https://archive.org/stream/heraldryworcest01 grazgoog\#page/n368/mode/2up.

111. FamilySearch, https://www.familysearch.org/search/tree.

112. EBC, FamilySearch, https://familysearch.org/ark:/61903/1:1:JQLQ-DWY, accessed 6 December 2014, Robert Morley, 25 Jan 1576.

113. FamilySearch, https://familysearch.org/search/record

114. Calendar of the Fine Rolls (hereafter (FR), Vol. XVII, Henry VI, A.D. 1437-1445 London 1937, p. 148, https://archive.org/stream/calendaroffine17greauoft\#page/148/mode/2up/.

\section{ABOUT THE AUTHOR}

John Morley was born in the Swansea Valley, educated at West Monmouth Grammar School in Pontypool, the Welsh College of Advanced Technology in Cardiff and the University of Manchester, where he obtained his PhD in 1967 and DSC in 1989. His early career was spent in industry with ICl, first at Grangemouth in Scotland and later at Blackley in Manchester. In 1984, he became visiting Professor of Chemistry at the Queen's University of Belfast and was later appointed to the senior management position of Research Associate in ICl. He left industry in 1994 to take up an appointment as Professor of Chemistry at Swansea University; he is the author of around 140 publications in Chemistry. He became an Emeritus Professor at Swansea University following his retirement, and has since taken a keen interest in genealogy. He has published around a dozen articles on this theme (see: https://jomorley9.wixsite.com/website) and he is a direct descendant of the Glamorganshire Morleys who are described in this article.

jomorley9@gmail.com 